Physics International 1 (1): 69-76, 2010

ISSN 1948-9803

(C) 2010 Science Publications

\title{
Freshwater Situation in Kuwait-Remote Sensing Inputs on Possibility of Artificial Recharge
}

\author{
${ }^{1}$ M. Al-Murad, ${ }^{2}$ S. Uddin and ${ }^{2}$ A. Al-Dousari \\ ${ }^{1}$ Department of Hydrology, \\ ${ }^{2}$ Departments of Environmental Sciences, \\ Institute for Scientific Research, P.O. Box 24885, Safat 13109, Kuwait
}

\begin{abstract}
Problem statement: Kuwait is an arid country having per capita freshwater consumption of 4851 day $^{-1}$. Almost the entire freshwater requirements are met through desalination. The water tariffs in the country are very low consequent to $60 \%$ subsidy provided by the government. The use of tertiary treated wastewater is restricted to irrigation and forestation; this leaves huge surplus that can be utilized for creation of shallow artificial aquifers. Approach: Remote sensing data provides information on existence of a paleo drainage network in north Kuwait which can be utilized for artificial recharge. Results: About $85 \%$ of treated wastewater which remains unutilized can be pumped into shallow aquifers creating future reserve. The shallow aquifers will also improve the soil moisture balance and shall support perennial vegetation, impeding dust transport. Conclusion: The pumping of tertiary treated wastewater into the paleo drainage network will create a future reserve besides improving the soil moisture index and vegetation cover in the area.
\end{abstract}

Key words: Wastewater, paleo drainage, vegetation cover, shallow aquifer

\section{INTRODUCTION}

Kuwait is located on the northwestern part of Arabian Gulf bordering Iraq in North and West and Saudi Arabia in South and southwest (Fig. 1). It forms part of the Middle Eastern arid lands. The country has scarce fresh water resources in form of few freshwater lenses and brackish fossil underground water in aquifers. Two tier aquifer systems exist in Kuwait, the upper Kuwait group aquifer of Quaternary age and lower Damman aquifer of Middle Miocene age. The Kuwait Group aquifer is unconfined, which is underlain by an Aquitard and confined Damman Aquifer, with upward seepage at few places (Ud Din et al., 2007). The water level in Kuwait varies from $90 \mathrm{~m}$ above mean sea level in southwest to zero at the Arabian Gulf coast in Northeast. The groundwater quality varies from brackish in southwest to highly saline in north. The Total Dissolved Solids (TDS) of brackish water is around $4000 \mathrm{pp} \mathrm{m}$, it is used for landscaping and irrigation, while the TDS of water in north exceeds 130,000 pp m (Burdon and Al-Sharhan, 1968; Himada and El-Yaqubi, 1979), which makes it unfit for direct use. Under these circumstances the only dependable fresh water alternative for Kuwait remains-desalination. The history of desalination in Kuwait dates back to
1951, when the first desalination plant was commissioned (Hamoda, 2001).

The scarce freshwater resource and the apathy towards water resource conservation make it imperative to look for solutions to bring sustainability in water resource of the region. Freshwater is not a free commodity available as of right for arid countries. There are huge costs involved in commissioning of desalination plants, their running cost and maintenance. The desalination cost in Kuwait is KD 1.993 (US \$ 6.577) per thousand imperial gallon i.e., $4546 \mathrm{~L}$ (Mukhopadhyay et al., 1994). The Government of Kuwait has provided a subsidy of over $60 \%$ to end users, who pay KD 0.800 (US \$2.64) per thousand imperial gallon. This huge subsidy in Kuwait, results in intensive use of freshwater, with daily per capita consumption of $485 \mathrm{~L}$ in year 2005 (Anon, 2005).

The water budget of the country is negative, with an average rainfall of less than $120 \mathrm{~mm}$ per annum and an excessive evaporation at rate of $16.6 \mathrm{~mm}$ day $^{-1}$, leaving a little possibility of recharge. However, study by Ud Din et al. (2007) in Raudatain basin, northern Kuwait suggests some promising theoretical results, where $22.38 \mathrm{MCM}$ of recharge was estimated in year 2003.

Corresponding Author: M. Al-Murad, Department of Hydrology, Institute for Scientific Research, P.O. Box 24885, Safat 13109, Kuwait Tel: + 96524989884 Fax: +965 24989819 
Phy. Intl. 1 (1): 69-76, 2010

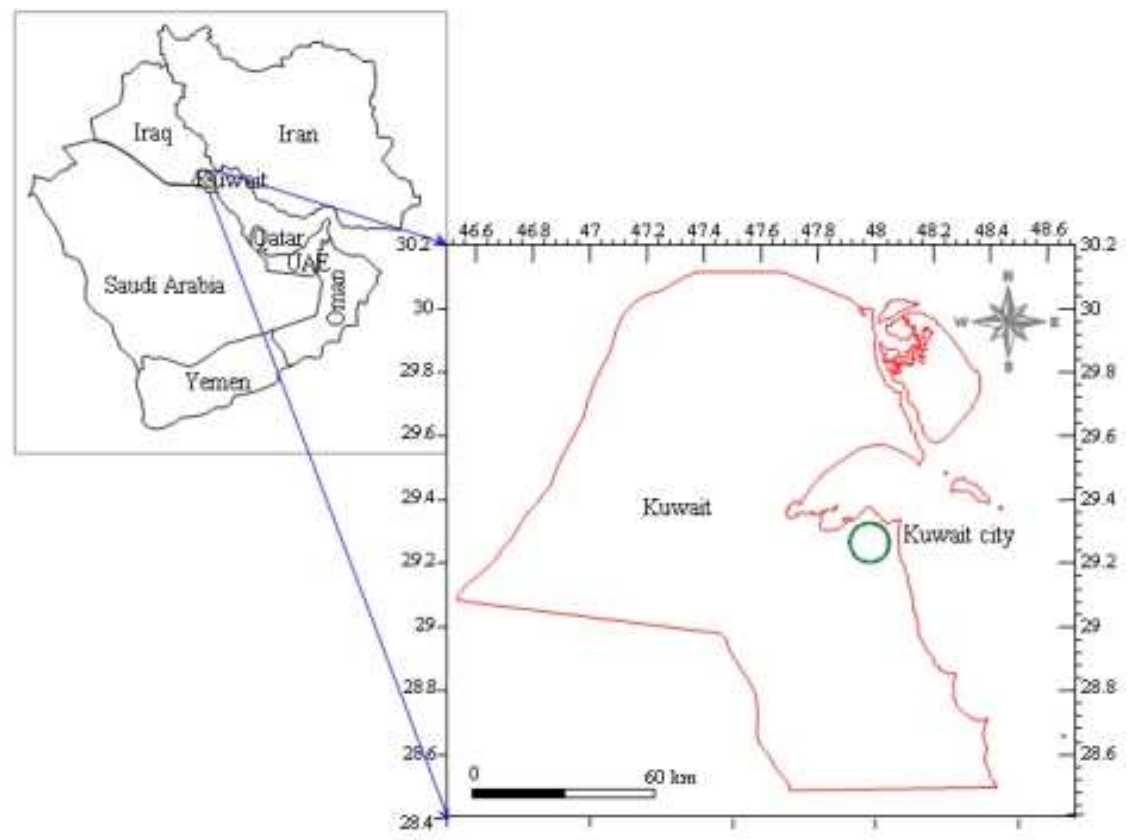

Fig. 1: Location map of Kuwait

Table 1: Annual fresh water consumption pattern of Kuwait

\begin{tabular}{lr}
\hline Year & Consumption (MCM) \\
\hline 1964 & 10.287 \\
1970 & 30.00 \\
1974 & 45.63 \\
1984 & 156.00 \\
1994 & 259.84 \\
1998 & 354.00 \\
2000 & 382.00 \\
2004 & 474.72 \\
\hline
\end{tabular}

Water consumption pattern in Kuwait: A detailed account of water consumption pattern in Kuwait is given by Ministry of Energy in their Statistical Year Books. Mukhopadhay et al. (2000) provided a review of water usage since 1970. The water consumption in Kuwait follows an upward trend since 1970. The total national fresh water requirement rose from 10.287 MCM in 1964-474.72 MCM in 2004 (Table 1).

The increase in fresh water consumption is proportional to population increase, besides it can be attributed to changing life style, increased piped water supply and high subsidy in fresh water tariffs. The ease of availability and huge subsidy is most pertinent cause for apathy towards effective water resource management, which is reflected as increase per capita consumption currently estimated at $485 \mathrm{~L}^{-1 a y}{ }^{-1}$ as compared to $113 \mathrm{~L} \mathrm{day}^{-1}$ in 1970 . To keep up with the increasing demand, Government of Kuwait has increased its desalination capacity from 123 million L day $^{-1}$ in 1970 to 1441.53 million $\mathrm{L} \mathrm{day}^{-1}$ in 2005 using multi-stage flash distillation. There is a planned increase to achieve capacity of 2102.53 million $\mathrm{L} \mathrm{day}^{-1}$ by year 2008 (Anon, 2005). The point of concern is that how much and how long can this trend be sustained, since desalination is an expensive alternative and huge investment is required in commissioning, maintenance and running of these plants. Moreover, continued desalination activity is resulting in increased salinity off coast, which may adversely affect the marine environment.

Management of water resources: The high consumption rate and scarcity of fresh water resources make it imperative to optimally utilize these freshwater resources. For better management and regulation of fresh water use, a public awareness campaign should be launched throughout the country. Use of water saving devices, such as aerators, low consumption cistern and flushes, should be made mandatory and a legislation could be brought in, to encourage production and/or sale of water saving plumbing fixtures only. Various studies indicate that water saving plumbing devices can cut consumption by 50\%; Even if there use in Kuwait can save about $25 \%$, then the per capita consumption will reduce to $363.75 \mathrm{~L} \mathrm{day}^{-1}$. This implies saving about US \$ 0.175 per head per day amounting to daily saving of US $\$ 437,500$ on total water usage (for an estimate population of 2.5 million). 
Phy. Intl. 1 (1): 69-76, 2010

Table 2: Average values of water quality parameters in tertiary treated wastewater in Kuwait (Alhamoud et al., 2003)

\begin{tabular}{ll}
\hline Parameters & Concentrations \\
\hline Total Suspended solids $\left(\mathrm{mg} \mathrm{L}^{-1}\right)$ & $1.5-8.8$ \\
Total Dissolved Solids & $1150-1400$ \\
Volatile suspended solids $\left(\mathrm{mg} \mathrm{L}^{-1}\right)$ & $1.2-6.0$ \\
Biochemical oxygen demand $\left(\mathrm{mg} \mathrm{L}^{-1}\right)$ & $5-10$ \\
Chemical oxygen demand $\left(\mathrm{mg} \mathrm{L}^{-1}\right)$ & $20-50$ \\
$\mathrm{pH}$ & $6.5-7.5$ \\
$\mathrm{NH}_{3}\left(\mathrm{mg} \mathrm{L}^{-1}\right)$ & $2.2-5.8$ \\
Sulfides $\left(\mathrm{mg} \mathrm{L}^{-1}\right)$ & 0 \\
Phosphate $\mathrm{PO}_{4}\left(\mathrm{mg} \mathrm{L}^{-1}\right)$ & $18.2-19$ \\
Temperature $\left({ }^{\circ} \mathrm{C}\right)$ & $26-28$ \\
Grease/oil $\left(\mathrm{mg} \mathrm{L}^{-1}\right)$ & 0 \\
Sodium absorption ratio & $8.0-10.0$ \\
Coliform $(\mathrm{MPN} / 100 \mathrm{~mL})$ & $1.0-2.0$ \\
Fecal coliform (MPN/100 mL) & $1-7$ \\
Egg parasites (MPN/100 mL) & $<1$ \\
Worm parasites (MPN/100 mL) & 0 \\
Fecal streptococci (MPN/100 mL) & 0 \\
Salmonella (MPN/100 mL) & 0 \\
\hline
\end{tabular}

Another option for better management of freshwater resource is reduction in subsidy, which will make users to pay the actual cost or a larger part of what they use. This increase in water tariffs is surely bound to bring considerable change in water usage pattern.

Introducing a system of incentive for saving fresh water can be another option. In this case each household can be given a subsidized quota for water, depending upon the household size. Any expense over the allocated quota will be charged as per penal rates to be determined by ministry of energy, where as those who save on their quota can be granted incentives as paying back for saved quota.

Introduction of waste water tax should be given a serious thought, since treating waste water involves cost, thus the polluter should pay towards cleaning this water. This shall in turn help in lowering per capita freshwater consumption.

Irrigating gardens using freshwater should be discouraged. The secondary and/or tertiary treated waste water and brackish water being supplied should be used for gardening and irrigation in urban areas. Washing cars, pavements and patios using freshwater hose should be discouraged. Penalty imposed by municipality could act as a much needed deterrent.

Waste water in Kuwait: The present tertiary treated wastewater production in the country is $0.4 \mathrm{MCM}$ day $^{-1}$ (Hamoda, 2001), whereas the total daily freshwater consumption is close to $1.65 \mathrm{MCM} \mathrm{day}^{-1}$. This lower production of treated waste water is attributed mainly to lack of water collection facility in some areas, prohibition of industrial effluent discharges into municipal waste water collection network and disposal of wastewater into sea after pre treatment to bring its characteristic to acceptable levels (Alhamoud et al, 2003).

There are four wastewater treatment plants in Kuwait at Ardhiya, Rekka, Jahra and Sulaibiya with capacities of $0.19,0.12,0.07$ and $0.375 \mathrm{MCM}^{-1}$ respectively, which treat the water to good quality (Table 2). The utilization of treated wastewater is quite low. Out of the total production of $0.4 \mathrm{MCM} \mathrm{day}^{-1}$ the irrigation and afforestation program utilizes only $15 \%$ of the total produce (Alhamoud et al., 2003). The public acceptance to treated wastewater is quite low. A survey was carried out by Alhamoud et al. (2003) which indicates total refusal to use treated wastewater on grounds of health risk, psychological repugnance and religious beliefs. However, it is interesting to note that $82.6 \%$ of the sample lacks any idea about the processes and basic understanding of tertiary treated wastewater. A small fraction of the sample comprising $5.2 \%$ was knowledgeable about wastewater treatments and use. This indicates the need of large scale public awareness campaigns to bring acceptance towards use of tertiary treated wastewater in Kuwait. Another interesting finding is the willingness to pay in order to avoid using treated wastewater. This can further be explored and sampled on a large scale to restructure water tariffs and reduce subsidy.

The cost benefit analyses indicates tertiary wastewater with zero Fecal coliform $/ 100 \mathrm{~mL}$ costs $\mathrm{KD}$ 0.574 (US\$ 1.8942) per thousand imperial gallon compared to KD 1.993 (US \$ 6.57) per thousand imperial gallon for freshly desalinated water. This cost saving of KD 1.419 (US \$ 4.6827) per thousand imperial gallons can save the country hundreds of millions Kuwaiti Dinars on its water bill.

Artificial recharge using tertiary treated wastewater: From the background it appears that there is general non acceptance of wastewater use and a very limited portion comprising only $15 \%$ of total treated effluent is used for irrigation and a forestation. The concept of pumping the treated water back to sea is not an economically viable alternative. The idea of creating artificial shallow aquifer in Kuwait group is probably a better option. Field experiments have been carried out by Kuwait Institute for Scientific Research to ascertain technical feasibility of artificial recharge in Kuwait (Senay, 1977; Mukhopadhyay et al., 1994).

Senay (1977) carried out artificial recharge experiment in Raudatain area, north Kuwait, where the target was upper Kuwait Group aquifer which is a shallow aquifer in this region. There was several injection experiments repeated in different wells where 
injection was carried out from 27-40 days at rates varying from $655-1309 \mathrm{~m}^{3}$ day $^{-1}$. Pumping test was carried out in all those wells which suggested that the TDS gradually increased after a month.

Mukhopadhyay et al. (1994) carried out several injection experiments in Upper Dammam aquifer, Lower Damman aquifer and Kuwait Group aquifer during 19891990 and demonstrated technical feasibility of artificial recharge in these aquifers. However, some problems relating to clogging from suspended solids and entrapped air were reported, but were solved by back pumping and acidification.

Remote sensing view: The satellite image analyses highlights presence of paleo drainage network in Kuwait, which are indicators of humid geological past. The northern Kuwait characterized by Dibdibah Formation (Fig. 2) is a paleo fan deposit of Wadi Al Batin, which is an extinct river system. These paleo channels have all the geomorphological characteristics of an active drainage. Infiltration tests carried out in various geomorphic and geologic formations shows playas have very low infiltration rates of 4-7 $\mathrm{cm} \mathrm{h}^{-1}$, where as the valley fill deposits show high filtration rates of $55-67 \mathrm{~cm} \mathrm{~h}^{-1}$ (Fig. 3). If the tertiary treated water is pumped upstream into this paleo drainage network which consists of valley fill deposits, it will allow both natural filtration and accumulation of the treated wastewater into the shallow Kuwait Group aquifer. The problem of clogging and air entrapment will be solved in this process.

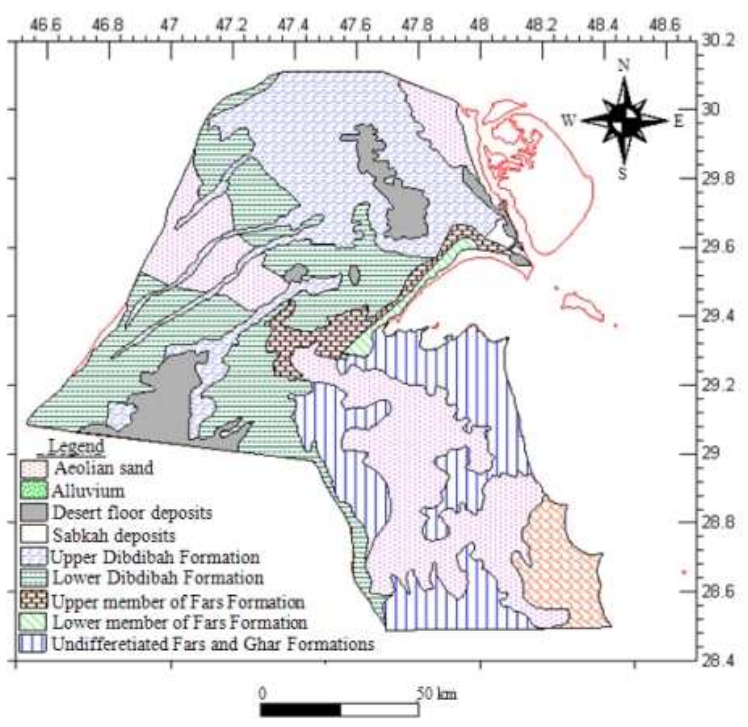

Fig. 2: Geological Map of the area
However there will be problem of high evaporation rates, which can be circumvented if the recharge is done through shallow wells of 3-4 $\mathrm{m}$ diameter within the paleo channels, it is presumed that the high infiltration rate of the valley fill deposits within paleo-channels will further minimize the evaporation losses by facilitating sub surface recharge. These wells can be spaced 50-100 m apart.

The benefits of utilization of paleo drainage are numerous; no cost is required to create underground reservoir. The paleo drainage in northern Kuwait is not under any major landuse except at places were gravel quarries were developed. The recharge to shallow aquifer will improve the soil moisture content and the vegetation cover in the area.

The remotely sensed data shows a contrast in vegetation indices in summers and winters. The satellite images of January to March show reasonable vegetation cover on the surface in form of grass, small shrubs and bushes (Fig. 4) which disappear from April onwards (Fig. 5). The precipitation in the region is usually around $120 \mathrm{~mm}$ which is unable to saturate the top soil for long, thus with increased summer temperatures the top layer becomes dry and vegetation is lost.

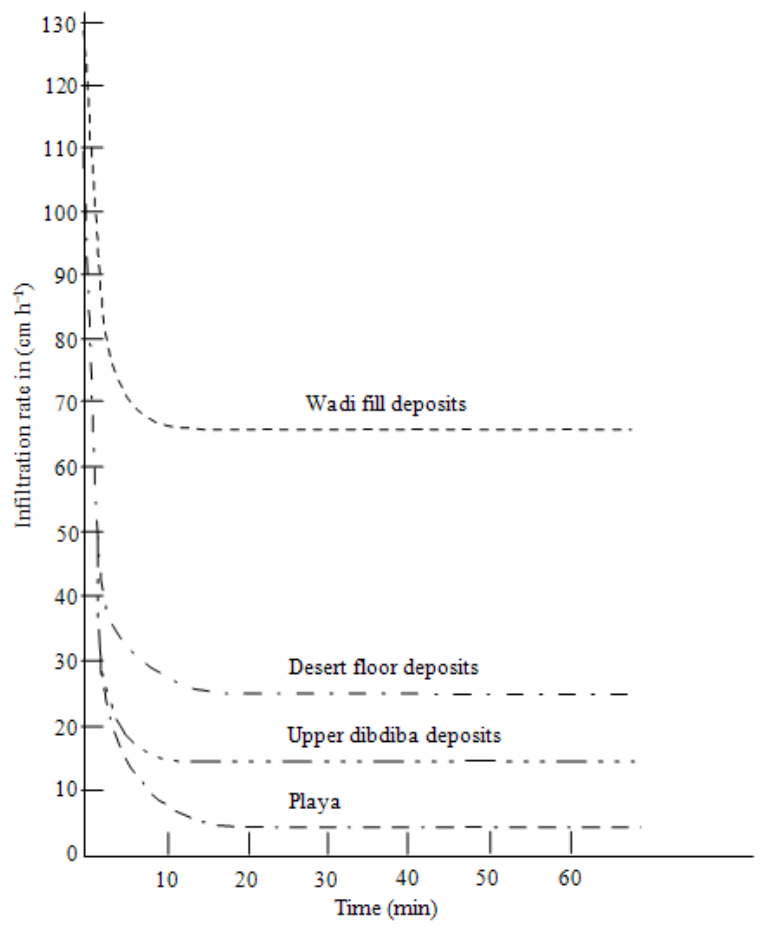

Fig. 3: Infiltration rates in different geomorphic and geologic units Modified after Al-Sulaimi et al. (1997) 
Phy. Intl. 1 (1): 69-76, 2010

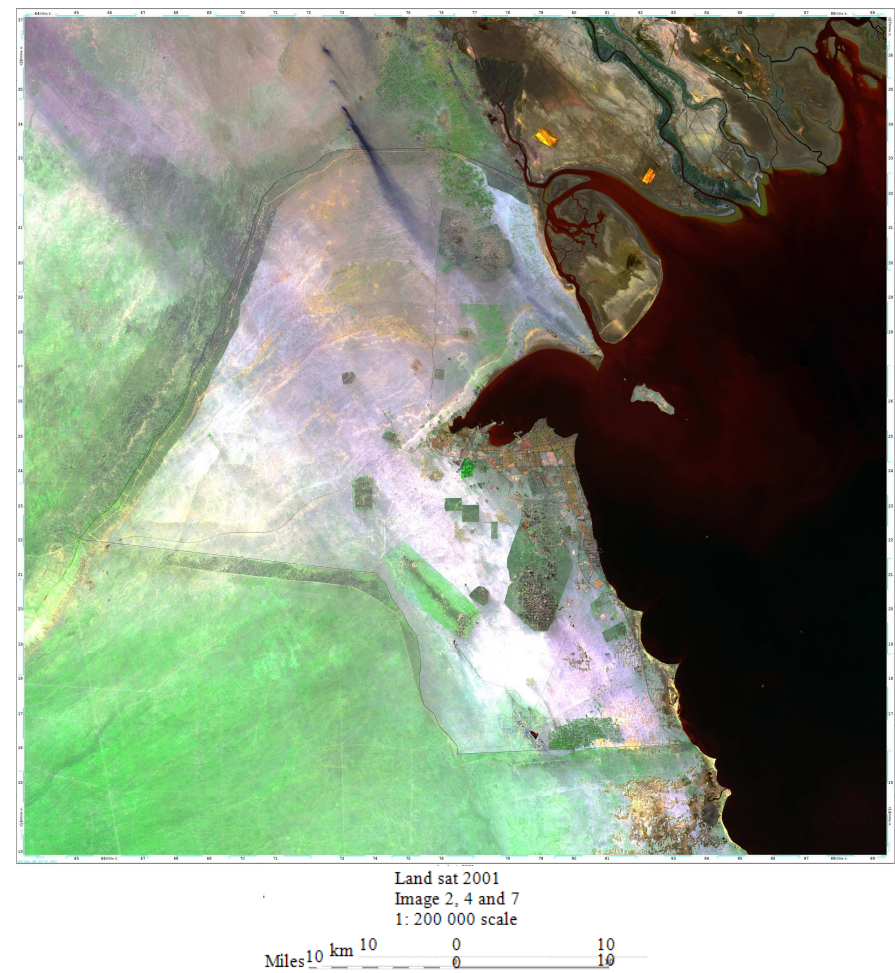

Fig. 4: Land sat image of March 2001 (vegetation is seen as green)

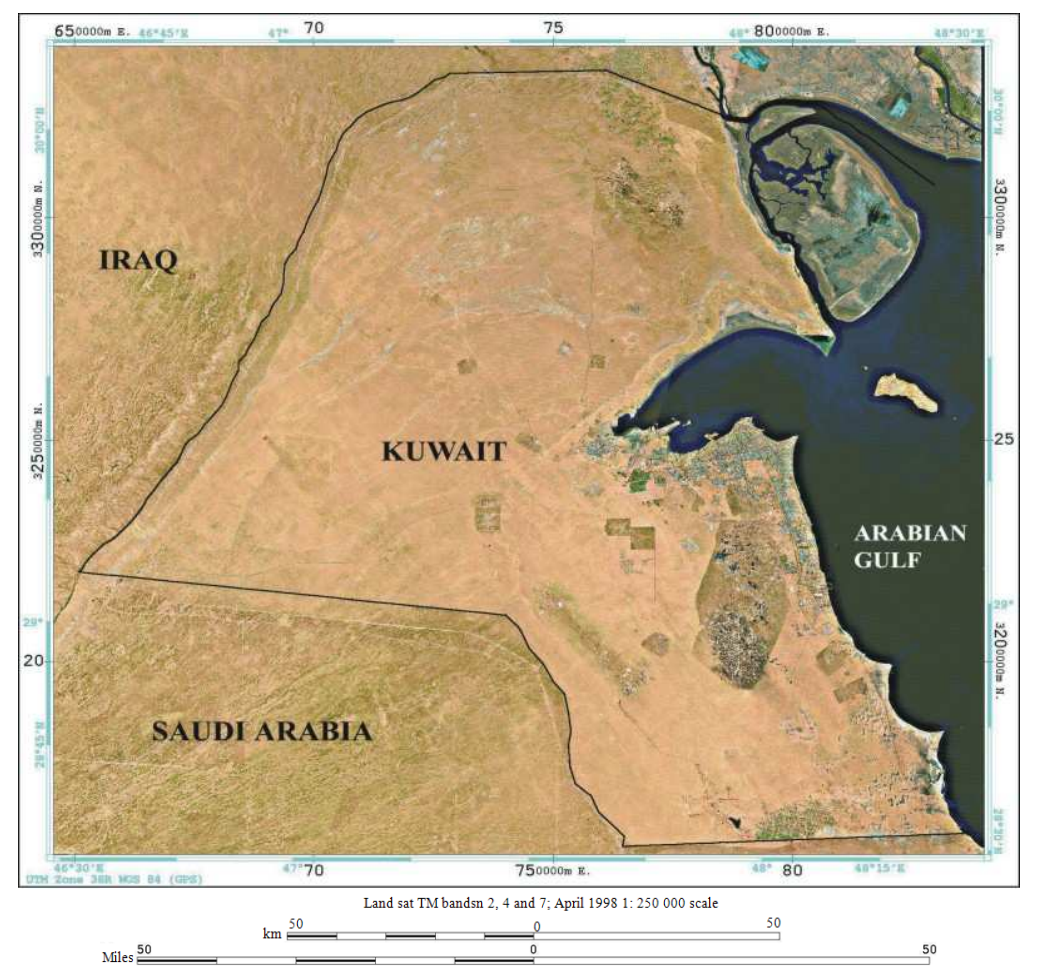

Fig. 5: Land sat image of April 1998 (vegetation seen as green) 
Phy. Intl. 1 (1): 69-76, 2010

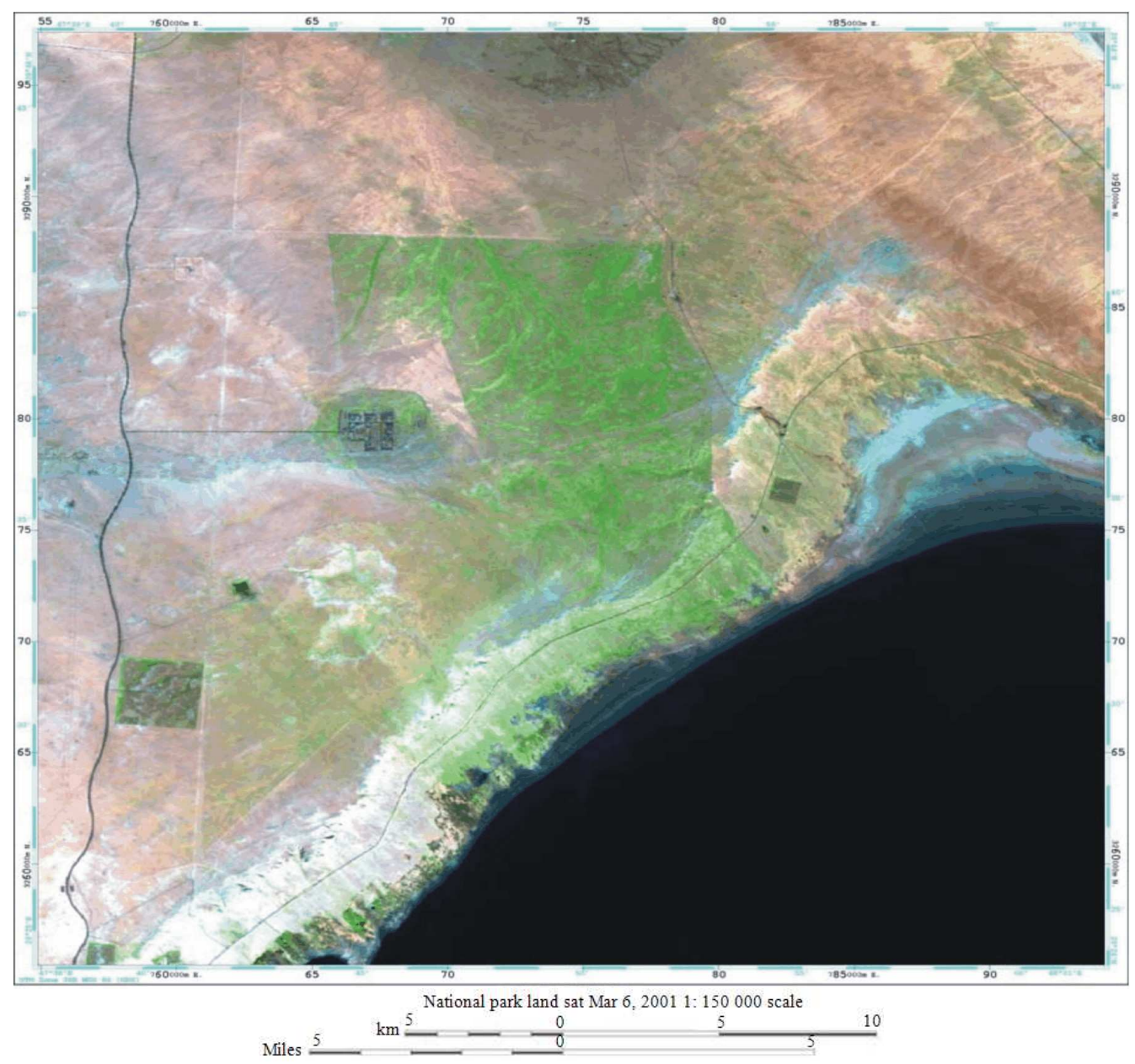

Fig. 6: Sabah Al Ahmad Reserve Park, Kuwait

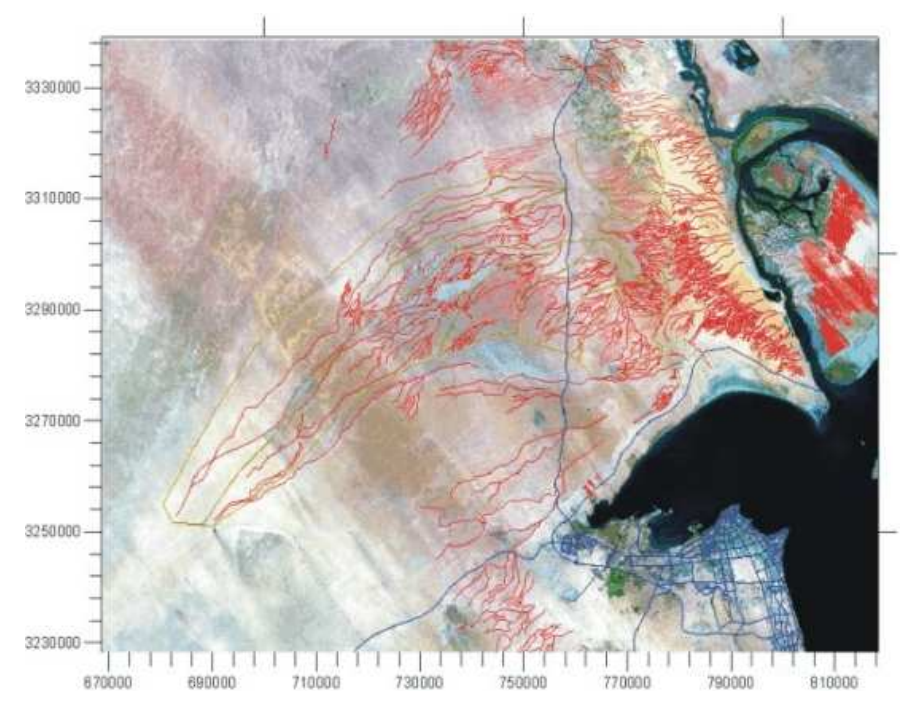

Fig. 7: Paleo drainage network in Northern Kuwait 


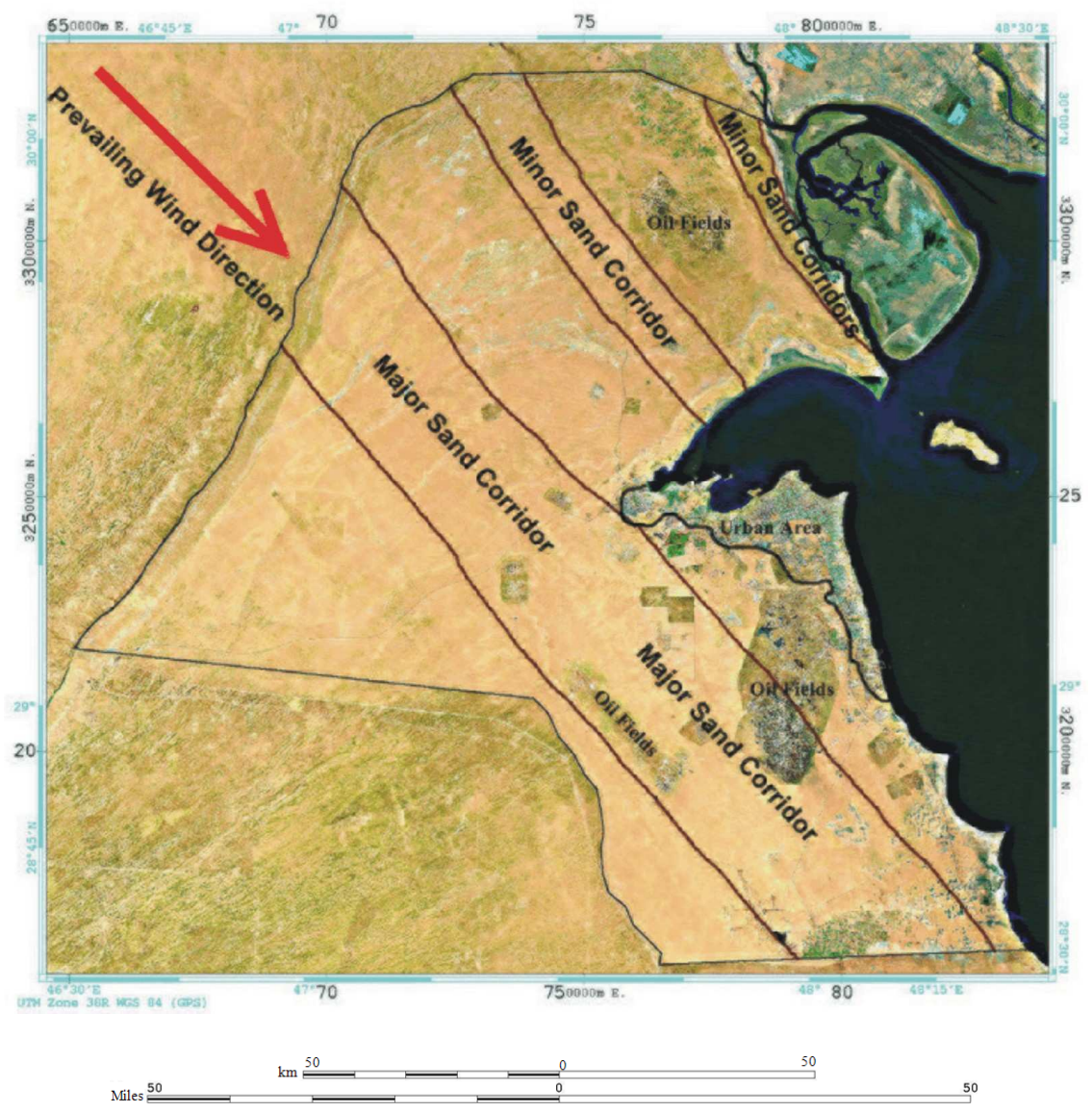

Fig. 8: Sand corridors in Kuwait

It is to be noted that some of the plants can sustain the heat of the desert, if they get the moisture or irrigation, a good example is the reserve park (Fig. 6), where perennial vegetation exists but there is reduction in surface greenery and only bigger shrubs sustain the heat as they are irrigated. The discharge of tertiary treated waste water into the paleo drainage will facilitate recharge into shallow aquifer resulting in improved soil moisture content perennially which in turn can support a better vegetation cover. The paleo drainage network in north of Kuwait is oriented northeasterly (Fig. 7) and it passes through the sand corridor of Kuwait (Fig. 8). Improved soil moisture and vegetation cover will retard free sand movement in the zone, hopefully creating a positive impact on stabilization of sand sheet and dunes in the area.

\section{DISCUSSION}

Water resource utilization in Kuwait is very high. The government had always ensured ample supply to its residents. The water tariffs are quite low due to huge subsidy provided by the government and the users don't feel the pinch. But apathy of users towards freshwater use makes it imperative to review the situation. Public awareness and legislation to use of water saving devices are need of the hour.

The country has huge facilities for wastewater treatment. The wastewater treatment plant at Sulaibiya is the largest facility of its kind in the world which uses reverse osmosis and ultra filtration membrane based water purification. Utilization of treated wastewater in Kuwait requires more emphasis. It is already being used in irrigation and forestation but leaves a huge surplus, which may be used to form artificial shallow aquifer for future usage. The shallow aquifer and recharge through the paleo drainage seems feasible due to high infiltration rates in these geomorphic units. The recharge will improve the soil moisture content and vegetation cover in Kuwait. The dried sludge can be dumped in the paleo drainage; this will improve the fertility and water retention capacity of the top soil. 
Phy. Intl. 1 (1): 69-76, 2010

\section{CONCLUSION}

The aim of the write up is to kindle interest among the scientists and water resource managers to looks into possibility of utilizing the natural drainage available in the area to recharge the treated wastewater. The utilization of the paleo drainage network for creation of shallow aquifers will circumvent need to construct, new surface or subsurface reservoir for storage of the treated wastewater. The spatial extent of the paleo drainage network makes it feasible to use it for irrigating the northern agriculture fields. However detailed investigations are required to study the rate of recharge and for locating the shallow wells to activate paleo drainage system, which may be used as future reserve.

\section{REFERENCES}

Alhamoud, J.M., H.S. Behbehani and T.H. Abdulllah, 2003. Wastewater reuse practices in Kuwait. Environmentalist, 23: 117-126.

Al-Sulaimi, J., F.J. Khalaf and A. Mukhopadhyay, 1997. Geomorphological analysis of paleo drainage systems and their environmental implications in the desert of Kuwait. Environ. Geol., 29: 94-111.

Anon, 2005. Statistical year book-water. Ministry of Electricity.

Burdon, D.J. and A. Al-Sharhan, 1968. The problem of the paleokarstic dammam limestone aquifer in Kuwait. J. Hydrol., 6: 358-404.
Hamoda, M.F., 2001. Desalination and water resource management in Kuwait. Desalination, 138: 385-393. DOI: 10.1016/S0011-9164(01)00288-0

Himada, I.H. and S.A. El-Yaqubi, 1979. Hydrogeological and hydrogeochemical aspects of the mail groundwater fields in Kuwait, Arabian Gulf. Proceeding of the 1st Geological Congress of the Middle East, (GCME'79), Ankara, Turkey, pp: $1-4$.

Mukhopadhyay, A., F. Szekely and Y. Senay, 1994. Artificial ground water recharge experiments in carbonate and clastic aquifers of Kuwait. Water Resour. Bull., 30: 1091-1107. DOI: 10.1111/j.1752-1688.1994.tb03355.x

Mukhopadhay, A., A. Akber, E. Al-Awadi and N. Burney, 2000. Analysis of freshwater consumption pattern in Kuwait and its implications for water management. Water Resour. Dev., 16: 543-561. DOI: $10.1080 / 713672535$

Senay, Y., 1977. Groundwater resources and artificial recharge in Raudatain waterfield. Ministry of Electricity and Water.

Ud Din, S., A. Al Dousari and A.N. Al Ghadban, 2007. Sustainable fresh water resources management in Northern Kuwait-a remote sensing view from Raudatain Basin. Int. J. Applied Earth Observ. Geoinform., 21 9: 21 DOI: 10.1016/j.jag.2006.03.001 